\title{
THE
}

\section{When Cultures Clash: Views from the Professions}

Norbert Hedderich

University of Rhode Island, hedderich@uri.edu

Follow this and additional works at: https://digitalcommons.uri.edu/ml_facpubs

This is a pre-publication author manuscript of the final, published article.

Terms of Use

All rights reserved under copyright.

\section{Citation/Publisher Attribution}

Hedderich, Norbert. "When Cultures Clash: Views from the Professions." Die Unterrichtspraxis / Teaching German 32, no. 2 (1999): 158-65. doi:10.2307/3531756. JSTOR, www.jstor.org/stable/3531756.

This Article is brought to you for free and open access by the Modern and Classical Languages and Literatures at DigitalCommons@URI. It has been accepted for inclusion in Modern and Classical Languages and Literatures Faculty Publications by an authorized administrator of DigitalCommons@URI. For more information, please contact digitalcommons-group@uri.edu. 
When Cultures Clash: Views from the Professions

Norbert Hedderich

University of Rhode Island

Introduction

The teaching of culture has been a major concern in foreign language education for decades and instructional materials generally cover a wide range of culture-related topics. In terms of addressing culture clash, a phenomenon experienced by anyone who ventures into a foreign country, the emphasis is often placed on observable behaviors commonly displayed by persons of the target culture. Whereas these observable behaviors receive attention, the underlying beliefs, attitudes, and values, on the other hand, are addressed less frequently.

This article reports the results of a series of interviews with Germans and Americans, aimed at identifying some of these core values and beliefs. As the group of informants of this study did not form a representative sample, the findings cannot be generalized to a wider population. They are intended as a point of departure for teachers of German and particularly those who are involved in preparing students for internship assignments in German-speaking countries.

\section{Review of the Literature}

The phenomenon of culture clash has been well documented by Ned H. Seelye, Alan Seelye-James and Paul Pedersen. Yet surprisingly little of the research in intercultural communication and its practical applications have entered the field of teaching German. The seminal studies in this area have been conducted by anthropologists (Hall and Hall), cross-cultural psychologists (Hofstede) and lately, international management experts (Trompenaars/Hampton-Turner; Lewis). The foreign language teacher reading these studies will find few references to language proficiency. Likewise, many instructional materials for German do not address those issues that are the focal point of classic cross-cultural training, such as cultural values, attitudes and style of communication, even though the debate on the role of culture in teaching German continues. Analyzing instructional materials, it appears the treatment of culture in the classroom has not changed significantly since Mark J. Webber summarized it aptly almost ten years ago:

Traditionally, four related factors have circumscribed the classroom "practice" of culture; (1) (sic) Culture was used as a motivator: in the positive sense, this meant that it was a (more or less keenly anticipated) break from the routine; in the negative sense, it meant that culture was a convenient rubric which could be employed whenever teachers and students were not capable of real teaching and learning, or there were a few minutes which needed to be filled; (2) (sic) culture involved the bringing in of "realia" or, more frequently, the use of audio-visual materials: this could result in a largely passive experience of culture by the students; (3) (sic) culture was seen as a number of facts about the country (countries whose language the students were learning; (4) (sic) these facts were treated as background information to the real business of the class, mastery of the target language. As such, they sometimes took on the character of items from Trivial Pursuit - little-known, perhaps intriguing, but unconnected bits of information. Overall, then, the scheduling and the presentation of culture meant that it was not treated systematically, but as discrete moments and items of nonessential information. (132)

Webber suggests that a mere presentation of isolated cultural facts which are different from one's 
own culture does not contribute to a genuine understanding of the target culture. He argues for a more integrated view of culture, advocates dealing with stereotypes in the classroom and provides suggestions for leading students from stereotyping to critical thinking.

The notion of culture implied in the quote above is in marked contrast to the definition provided by Gert Hofstede, a Dutch social scientist and leading figure in intercultural theory. In Culture's Consequences: International Differences in Work-Related Values, he writes: "Culture is the collective programming of the mind of members of a group, which is reflected in its particular assumptions, perceptions, thought patterns, norms and values" (6). The present study identifies some of these underlying values and perceptions and provides a rationale for cross-cultural studies in the German classroom. Some may argue that intense cross-cultural study in the German-American context is unnecessary. The casual observer who has not experienced culture clash could easily get this impression from the literature in cross-cultural studies and by comparing the popular cultures of the two countries. In some of the theoretical frameworks, Germans and Americans rank fairly close to each other when contrasted with Mediterranean, Latin American and Asian cultures. An example is the issue of high context versus low context cultures, a key cultural concept.

According to Hall and Hall, in a high context communication or message, "most of the information is already in the person, while very little is in the coded, explicit, transmitted part of the message" (Understanding Cultural Differences 6). High context peoples such as the Japanese, Arabs and Southern Europeans develop extensive informal networks for information and pay more attention to non-verbal signals. Also, information is said to spread unofficially more rapidly in high context countries. Low context peoples, on the other hand, such as Americans, Germans, Swiss, Scandinavians and other Northern Europeans "appreciate explicit, clear, written forms of communication, as provided by computers, books, reports, and letters" (Leeds, Kirkbride and Durcan 12). Hall also attempted to place various countries on his low-high context dimension, a listing which has largely been accepted by subsequent research.

\section{TABLE 1}

In Hall's listing, West Germans and North Americans are only one point apart with respect to this particular concept. As the present investigation found, this apparently small difference can account for significant points of conflict between Germans and Americans.

The casual observer of the popular cultures in Germany and the US may also get the false impression that cultural differences are negligible. American music, American style clothing and American fast-food chains have become part of German life. Even though the US cultural influence has been strong since the end of WW II, it appears to have intensified. The changed programming on German television since the introduction of commercial television in 1985 is but one example. Most recently, the continued advance of English as the lingua franca of business and the increased use of the internet, dominated by the English language, have contributed to this impression.

\section{Purpose of Study}

Students who embark on internships abroad face multiple challenges. Many of them have not yet reached advanced level proficiency in German. As far as pre-departure preparation is concerned, a host of critical issues demand immediate attention, such as placement, visas, health insurance, housing, etc. In light of these pressing issues, intercultural preparation often gets cut 
short. The intention of the present study was to gather information that will provide the basis for a more systematic treatment of cross-cultural issues in the classroom. The overall objective was to identify workplace related intercultural differences between Americans and Germans. Specifically, the investigation sought answers to the following questions: -Is culture clash a significant factor for Americans working in Germany? -If so, where do Americans and Germans see the major points of conflict?

-What is the best advice we can give American students who go on internships to German-speaking countries?

\section{Sample and Method}

Twenty persons with German-American intercultural experience were interviewed. The subjects were identified through company contacts of the University of Rhode Island's International Engineering Program. The small scale of the project allowed only for a limited number of informants. The author interviewed twenty subjects, ten Americans and ten Germans, each of whom had spent a minimum of six months in the other country; many had a multi-year, extensive experience in dealing with employees from the other country. Each group included an "international," in one case a French citizen who has been working for an American company in Germany for more than ten years and also had worked two years in the US, in the other case, a Dutch citizen who attended college and graduate school in the US, and has been working for a German company in the US but at the time of the data collection was working for that company in Germany. The twenty interviewees worked at eight different companies, four of them were German businesses, the other four were subsidiaries of American corporations.

Even though the intended outcome of the study was to benefit primarily Americans who are sent to Germany, an equal number of Germans who had extensive cross-cultural contact were interviewed, in order to ascertain the views of both sides. However, as the major focus of the study was to elicit key items of potential culture clash, the results are broken up by nationality only in cases where the two sides stressed different points.

The interviews were conducted in Germany in the fall of 1998. Extensive note-taking was chosen over tape-recording. The presence of a tape recorder would have caused some interviewees to be less open and frank, since culturally sensitive issues were discussed. The quotations provided in the results section are verbatim, some of the quotations by German informants have been translated into English.

While the sample is not perfectly homogeneous, the key criterion - having worked at least six months in the other country - was met by all twenty interviewees. The German group consisted of seven men and three women, the American group of nine men and one woman. The companies included small, mid-size and large firms, representing different branches of industry. The automotive sector was the most frequent, accounting for exactly half of the interviewees' companies. The breakdown of positions of the twenty subjects was as follows: Technical staff (engineers, technicians, chemists) $60 \%$; business staff (sales, accounting) $20 \%$; personnel $15 \%$; other $5 \%$. The foreign language proficiency, based on self assessment, was at least advanced for nineteen of the twenty interviewees.

In order to elicit as many items and examples of potential culture clash, the interviews were kept fairly unstructured and open ended. The investigator did break the interview into three parts by asking each interviewee the following three main questions. The first was asked to establish some background information on the interviewee.

- $\quad$ In what way and how long have you had contact with persons from the other culture? 
- In your opinion, where are the major points of cultural differences between Germans and Americans, if any?

- What advice would you give Americans who go on internships in German-speaking countries?

Results

With any treatment of cultural differences, particularly when comparing attitudes, beliefs, and national characteristics between two or more countries, one enters the dangerous territory of possible clichés. The views presented here are solely those of the twenty interviewees. Yet, in summary statements, some generalizations are necessary in order to arrive at meaningful comparisons. The author concurs with Richard D. Lewis who presents the following warning label:

Such generalizations carry with them the risk of stereotyping as one talks about the typical Italian, German, American, etc. It is evident that Americans differ greatly from each other and that no two Italians are alike. However, my experience during thirty years of living abroad and rubbing shoulders with individuals of many nationalities has led me to the conviction that the inhabitants of any country possess certain core beliefs and assumptions of reality which will manifest themselves in their behavior. (3)

Common themes emerged from the interviews, the most frequently mentioned items are dealt with first. All interviewees were eager to share their views and said they believe significant cultural differences exist between Germans and Americans. Seventeen of the twenty interviewees said they adjusted well to the new circumstances after a three-to-six-month period in the other country.

\section{Umgangston}

The interviewees generally agreed that the German work environment is characterized by a more business like atmosphere. The most frequently cited example was small talk. Most of the Americans were initially taken aback by the lack of casual conversations about family and hobbies. Eager to quickly establish a certain level of rapport with their German colleagues, many were puzzled by the lack of interest in casual conversation on part of the Germans and took it as a personal affront. One American interviewee, in a managerial position in Germany, felt especially handicapped by this phenomenon. "At home, I like the interaction with my team. Here, it doesn't seem possible. If I had this kind of relationship with team members in the US., it would be considered dysfunctional." As time passed, this issue became less of problem for the Americans, and they developed a greater comfort level in interacting with their German peers.

For the Germans describing their experience in the US., this phenomenon was a source of confusion in a different sense.

The more casual style of interaction (die lockerere Umgangsart) among Americans was a pleasant surprise. In addition, Germans found a degree of helpfulness toward the newcomer in the US. that they were not accustomed to. This welcoming into the culture and the feeling of having been made part of the group - one German engineer used the metaphor mit ins Boot nehmen- clearly made a lasting impression. About half of the Germans went on to explain that their German cultural frame of mind misinterpreted the openness of their American counterparts. A classic example is the invitation into the home of a co-worker, which, according to the interviewees, is by far more likely to happen in the US than in Germany. To the culturally 
uninitiated Germans working in the US, an invitation signaled at least the interest in establishing a longer-lasting friendship, but this was not followed up. Some of the Germans considered this a "superficial attitude." One respondent called it "a form of self protection resulting from the high degree of mobility in the US."

Attitudes towards Work

All the American interviewees and most of the German interviewees commented on a different system of attitudes relating to work in

Germany which explain some of the items mentioned earlier. In their opinion, there is a clear separation between work and home in Germany; in the words of one American, "work is work and play is play, there is more emphasis on family, free time, Urlaub and other values among Germans." Overall, Germans spend far more time away from work than Americans do. The American engineers were surprised at the shorter working hours of their German counterparts. "Everybody leaves work when it is Feierabend." At the managerial level, though, considerable overtime is expected in Germany as it is in the US.

\section{Positive Thinking}

Both Americans and Germans noticed more positive thinking and an upbeat attitude in the US culture. Maintaining an overall positive atmosphere is considered a high priority in the American work environment. One American observed "in Germany praise is the absence of criticism." Germans, while in the US were confused when they were repeatedly praised for what they considered accurate completion of routine tasks.

Other examples include presentations and letters of recommendation. In presentations given by Americans, some of the German interviewees found that negative aspects of a particular issue were not labeled as such but were listed under a heading such as "items for improvement," or were dropped altogether. One of the German interviewees commented as follows: "Ich fand das positive Denken der Amerikaner sehr verwirrend. In Deutschland wird viel weniger gelobt. Das Loben in Deutschland tun wir nur verhalten. Amerikaner sagen immer "good job"; wenn etwas schlecht war, sagen wir dagegen 'das war Mist.' " To one of the German interviewees American positivism was "distraction from genuine problems." Letters of recommendation were another example. "Deutsche Referenzen sind im Ton zurückhaltend, amerikanische dagegegen sind eher überschwenglich." This example supports the notion that Americans display more high context behavior than Germans.

\section{Core Values: Rapport vs. Truth}

In American meetings, it was observed, the manner in which a group arrives at a consensus is important. Keeping an overall positive, friendly rapport and avoiding personal attacks ranks high among Americans. "In the US, it doesn't rock the boat if the rules have to be bent a little to achieve the goal," said one American. Interviewees observed on the other hand a stricter adherence to truth and exactness in Germany as a core value. An interesting example is the American practice of signing a document for someone else. In many US offices, there is a mutual understanding that a subordinate or colleague can sign routine paperwork using the superior's name in case of absence of the superior. "In the US signing when the boss is out makes the wheels run," said an American interviewee. When trying to do so in Germany, the same person was met with shock, disbelief, and a clear message that he could be put in jail for such an action. 
Greetings and Forms of Address

In Understanding Cultural Differences, Edward T. Hall and Mildred R. Hall comment on the concept of space and increased territoriality in Germany (37). Almost all the American interviewees observed more formal greeting rituals in Germany particularly when entering people's offices. One American described the following situation, which he observed at the beginning of his stay in a large southern German firm. Early in the morning, he and his three colleagues who shared an office were sitting at their desks, discussing an urgent production problem. Their supervisor came in and - before delving into details-, he went around to each desk, greeted each member of the group and shook hands. Other American interviewees similarly reported that it took time to get used to the daily handshake as well as the ubiquitous lunch time greeting "Mahlzeit."

Most Americans also commented on the use of the formal Sie versus the familiar Du. Overall, the familiar form is used much more frequently in the workplace than commonly assumed. Most of the Americans reported that $\mathrm{Du}$ was used in their immediate, German-speaking peer group. Age and position in the company tended to be the key factors for the use of Sie versus Du. Interviewees reported that managers and persons considerably older were not addressed in the familiar unless that person offered the Du. At the managerial level, the $\mathrm{Du}$ address is found less frequently. The use of $\mathrm{Du}$ between supervisors and subordinates continues to be rare. It was most common in those companies that had a high degree of internationalization or were American owned.

\section{Fast Pace vs. Detail}

Almost everyone mentioned clear differences between Germans and Americans on the following concepts, which tend to be linked with each other: pace, attention to detail, and short-term vs. long-term thinking. These points were major sources of friction between the two sides. In the German firms, the planning process of a project tends to be long and very detail oriented. Plans are not implemented until they have been reviewed thoroughly. In the words of one American chemist: "The Germans will say: 'Let's try it one more time'; the Americans think Germans are testing things to death." For the American, gut feeling that a plan will succeed is enough." A German personnel manager whose company had recently been bought by an American firm said: "In groups where German and American engineers work together, we experience over and over again that the Germans want to plan far more thoroughly (gründlich), whereas the Americans are content with having completed $80 \%$ of the planning and then say; 'Let's begin.' The Americans constantly tell us to 'move faster.' We are struggling with an immense pressure to make faster decisions."

\section{Short-Term vs. Long-Term Thinking}

This item is a frequently discussed topic in the German-American business context. It can be partially explained by the different reporting systems American and German stock corporations must adhere to. Publicly traded German companies must report results to their shareholders only once a year, whereas American companies are required to do so four times a year. In addition, a significant portion of companies in Germany are privately owned and therefore have no reporting requirements at all. There is considerable pressure on American management and things change at a faster pace. Personnel changes are one example. An American plant manager who had been on assignment in Germany was informed at the 
beginning of the month that he was to return to the US at the end of the same month.

"Unthinkable in Germany," responded a German personnel manager. Many of the interviewees in this study, both Germans and Americans, commented on this aspect. They labeled the American style 'goal-oriented and action-oriented.' "Achieving the goal in a given time period is critical in the US There is an emphasis on meeting expectations," said one interviewee. Germans, on the other hand, are more concerned with exactness and providing all the necessary details.

One German interviewee said: "Americans work two to three times faster than Germans, they are very goal oriented, but if the plan does not work, they will completely throw it overboard after three months. It is much more difficult to change a plan in Germany once it has been implemented."

A strong orientation toward action among Americans was a major and recurring theme in the interviews, expressed mostly by German interviewees (Aktionismus). It was perceived as a pervasive concept in the American work culture. As it clearly clashes with the detail-oriented, long-term thinking of the German work culture, some of the Germans viewed it critically. One of the German interviewees said: Die Deutschen denken, die Amerikaner tun etwas, damit etwas gemacht wird.

\section{Creativity, Innovation and Independence}

Action-orientation versus attention to detail lead to the topics of creativity and innovation, which were on the mind of all American interviewees and were mentioned as a significant difference by some of the Germans as well. "My American colleagues and I keep a list of creativity killers," said a clearly frustrated American-trained engineer working in Stuttgart. "I often hear: 'No, this won't work'; 'we've tried this before,' and here is my favorite one: 'Things are different in the US." He reported "a resistance to alternatives," a "box-like thinking," an "unwillingness to just talk about a subject, if unprepared" and a "general risk aversion in the culture." One of the German interviewees who had spent a year in Texas pointed out: "In den USA findet man mehr Kreativität. Man geht nicht immer den geraden Weg zum Ziel. Die Amerikaner schränken sich weniger mit Regeln ein. Sie sind innovativ. Auf der anderen Seite sind sie weniger gut beim sturen Abarbeiten - Dinge, die getan werden müssen." In Hidden Differences: How to Communicate with the Germans, Hall and Hall call this phenomenon compartmentalization (50). Many of the interviewees, particularly the Americans, mentioned it by talking about different approaches to team work in the two cultures. In general, they reported less interaction with colleagues in the German work environment and said more independence was expected in Germany. One engineer described his notion of compartmentalization very vividly as the 'over the wall' phenomenon: "You develop the idea yourself. Then you throw it over the wall to the next person. You are done with it. It is now someone else's responsibility." He considered this procedure inefficient. The same person observed difficulty interacting with people from different departments in Germany with the following example:

I needed to have something done by a person in a different department in order to move on with my project. As I would have done in the US, I went to that person and asked him if he would provide me with the necessary information. He said no, claiming that was not part of his responsibilities. I then asked my boss, who asked the other person's boss to talk to his subordinate and request the information. This way it finally got finally done. 
The interviewees also observed a different role of the manager in the two business cultures. Many observed that American managers play a more active role and appear to have more power in the decision making process. Although the Americans are given plenty of room for brainstorming, the final decision often rests with the manager. One German interviewee observed that American managers, even though they encourage brainstorming, tend to give more detailed instructions. "Deutsche Manager dagegen erwarten in der Regel selbstständiges Handeln, sie würden genaue Instruktionen als Bevormundung auffassen."

Many interviewees commented on the relationship to management, on working independently and on having open discussions with supervisors. An interesting issue is challenging a manager's decision or opinion. Americans were surprised by the degree to which Germans challenged the opinion of a superior. In one American-owned company, the American managers found it unusual that their German subordinates wanted to talk about performance reviews. In the words of the German personnel manager of this company: "Die Welt denkt, die Deutschen seien obrigkeitshörig. Ein weitverbreitetes Klischee. Die Tatsache ist, das ist ganz anders seit '68. Die Menschen hier haben Schutz vor Entlassungen durch das Arbeitsrecht."

\section{Communication Style}

The above mentioned different attitudes towards time and detail can also be seen in different styles of communication. One interviewee used presentations as an example for culture clash. In his company Germans and Americans worked closely together in the first years after an American takeover. The presentations given by Germans tended to be long (about an hour), included the historical development of the project and contained numerous details about how the project was to be implemented. The important items were placed at the end. "The Americans got bored and grew very impatient," reports one interviewee. The presentations given by Americans on the other hand tended to be shorter (30 minutes), were animated and often began with a joke. The presenters focused on the action to be taken, provided the key information at the beginning and supplied less detail than their German counterparts.

In this company, the Germans reported that the culture clash described above was compounded by the language barrier. The Germans had to present in English, and despite extensive language training in English they experienced difficulties expressing themselves and "selling" themselves. "If everything goes through the English-language filter, you just cannot get the message across very clearly. I felt reduced to one quarter of the person I am," remarked one of the Germans in this group.

As problematic as this issue sounds, the most hopeful signs for resolutions to the culture clash issue came from companies, where the contact between Germans and Americans was most intense. In the company described above, mutual feelings of culture clash decreased as the American boss made progress with his German language training, began to speak German and experienced the kind of helplessness (kam sich wie ein Kind vor) the Germans had gone through.

The above-mentioned German manager, while disagreeing with many of the business practices of his American counterparts, saw positive changes in his firm because of the American influence.

Wir sind im echten Sinne internationaler geworden und haben unseren Horizont erweitert. Die Amerikaner haben eine offenere Informationspolitik, und wir haben davon gelernt. Unsere Vorstandssitzungen laufen jetzt entspannter ab. Zum Beispiel nehmen die einzelnenen Abteilungsleiter jetzt auch 'mal junge Sachbearbeiter mit, die etwas präsentieren. Ihnen wird applaudiert. Das ist sonst in Deutschland nicht üblich. 
Misunderstandings also arise from the issue of directness versus indirectness in the language. According to the interviews, verbal messages in Germany tend to be more direct than in the US, where they often are softened with expressions of politeness. The following example of a communication between Germany and the US illustrates this point. In a fax to a US firm, a German employee writes: "We need this information by...." For the US partner, this is an unambiguous message and she provides the required information in due time. In a comparable situation, the US employee faxes to her German counterpart "We would like this information by.... ." To the German counterpart, this type of wording may signal that this matter is not urgent and consequently the request is not completed by the required date. One of the American interviewees adapted to the more direct style of communication. "I have noticed the more flowery language of Americans; now I find the directness of the Germans refreshing, there is no doubletalk."

\section{Interviewees' Advice}

In the last question of the interview, the participants were asked what advice, based on their own personal experience, they would give young Americans who are going on an internship to a German-speaking country. While focusing on adjustment at work, interviewees were also encouraged to comment on all aspects of the overseas experience. There were numerous comments and they covered a wide spectrum of suggestions, from attitudes to very practical advice. As this information was given in the form of "do's and don'ts" it will be rendered here in that fashion.

\section{Before Going Abroad}

- $\quad$ Become as proficient in the language as possible before you leave. Take advantage of intensive courses in the US or in Germany.

- $\quad$ Read as much as possible about the country as you can (survey knowledge of history, geography, politics, economy, current issues, etc.). You will get more out of your stay and the people you are interacting with will appreciate it if you come informed.

\section{At Your Place of Work}

- $\quad$ Lower your expectations, especially in the first three months of your stay. It takes time to get used to living and working in a different culture.

- $\quad$ Don't be brash and try to impose American ways. Try to take in what you experience without immediately making judgments.

- $\quad$ Expect to work independently. You may see your supervisor less frequently than expected.

- $\quad$ Don't be afraid to take initiatives, to ask questions and to ask for different type of work or projects. You won't get it if you don't ask. This holds true especially in Germany. Outside of Work

- $\quad$ Expect diversity. Germany is not a homogeneous culture. Life is very localized.

Language, food, customs will vary from region to region.

- $\quad$ Don't take it personally if people seem distant and reserved to you at the beginning. It may be as difficult for you to get used to this as it is for a German visitor to the US when asked by a stranger "How are you?"

- $\quad$ Be patient when it comes to getting to know people. Closer contact comes with time.

- You will achieve the best results in your language proficiency and your stay will be more enjoyable if you have German friends. As most Germans separate work and private lives more than Americans, don't count on being able to get together with colleagues after work. Instead, 
find people with whom you share a common interest, join a Sportverein, Schachklub, etc. You will find a number of Vereine in even the smallest town.

Table 1

\begin{tabular}{lll}
\hline Country & High Context & $\begin{array}{l}\text { Low Context } \\
\text { West Germany }\end{array}$ \\
German Swiss & & $\mathrm{xxxx}$ \\
Scandinavian & & $\mathrm{xxx}$ \\
North America & & $\mathrm{xxx}$ \\
Belgium, Holland, Denmark & & $\mathrm{x}$ \\
France & $\mathrm{x}$ & \\
Great Britain & $\mathrm{xx}$ & \\
Southern European & $\mathrm{xxx}$ & \\
Middle East & $\mathrm{xxx}$ & \\
Asia, Africa, Latin America & $\mathrm{xxx}$ & \\
Japan & $\mathrm{xxxx}$ &
\end{tabular}

(Source: Leeds, Kirkbride and Durcan 13)

Works Cited

Hall, Edward T. Beyond Culture. New York: Anchor, 1976.

Hall, Edward T., and Mildred R. Hall. Hidden Differences: How To Communicate with the Germans. Hamburg: Stern, 1983.

---. Understanding Cultural Differences. Yarmouth, ME: Intercultural Press, 1990.

Hofstede, Geert. Culture's Consequences: International Differences in Work-Related Values.

Beverly Hills, CA: Sage Publications, 1980.

Leeds, Christopher, Paul S. Kirkbride and Jim Durcan."The Cultural Context of Europe: A

Tentative Mapping." Human Resource Management. Ed. Paul S. Kirkbride. London: Routledge, 1994. 11-27.

Lewis, Richard D. When Cultures Collide: Managing Successfully across Cultures. London:

Nicholas Brealy Publishing, 1996.

Markowsky, Richard, and Alexander Thomas. Studienhalber in Deutschland: Interkulturelles

Orientierungstraining für Amerikanische Studenten, Schüler und Praktikanten.

Heidelberg: Roland Asanger Verlag, 1995.

Pedersen, Paul. The Five Stages of Culture Shock: Critical Incidents Around the World.

Westport, CT: Greenwood Press, 1995.

Seelye, H. Ned.Teaching Culture: Strategies for Intercultural Communication. Lincolnwood, IL:

National Textbook Co., 1984.

Seelye, H. Ned, and Alan Seelye-James. Culture Clash: Managing in a Multicultural World. 
Lincolnwood, IL: National Textbook Co., 1995.

Trompenaars, Fons, and Charles Hampton-Turner. Riding the Waves of Culture. Understanding Diversity in Global Business. 2nd Ed.

New York: McGraw-Hill, 1998.

Webber, Mark J. "Intercultural Stereotypes and the Teaching of German." Die Unterrichtspraxis/Teaching German 23 (1990): 132-41. 